\title{
SCHOOL ADMINISTRATORS' PERCEPTIONS OF SCHOOL CONVERSION AND THE ACADEMIES ACT 2010: A CASE STUDY OF ONE SECONDARY SCHOOL IN NORTHERN ENGLAND
}

\author{
J H P Ariyaratne \\ Assistant Director of Education, Ministry of Education, Sri Lanka
}

\begin{abstract}
The study explored the perception of school administrators regarding the academization of schools which were initiated in 2000 in the UK. Since then this initiative allowed the government to force schools deemed to be failing to be partnered with sponsors and freeing the schools from their Local Education Authorities (LEAs). Some high performing schools were turned to converter academies but without the need of sponsors which later recruited other schools that were deemed to be failing to form multi-academy trusts (MATs). And the main objective of sponsored academies and MATs was to increase the performance of the lower-performance schools influenced by neo-liberal practices so that they are operated as business-like. The research utilised case study methodology - interpretivist approach — and interviews to collect data. The sample included two senior management members from a sponsored academy in a MAT. The findings revealed that the changes and impacts of being converted to an academy were largely attributed to leadership rather than to MAT. Thus, questioning the overall effectiveness of the academy programme by the school administrators. Furthermore, implementing changes that are neo-liberal in nature did compromise achieving Keynesian values and such interventions were questioned for their effectiveness by the school leaders.
\end{abstract}

KEYWORDS: academy act, neo-liberalism, Keynesian system

\section{INTRODUCTION}

Academies are the latest measures to inculcate neoliberal values in the education system in the UK. Since their establishment, the academies have gone through drastic changes resulting in different types of academies during their operation. These different types of academies include city academies, sponsored academies, converter academies, multi-academy trusts (MATs) and free schools (Gorard,2014; Walford, 2014b; West, 2014) addressing different issues and economic trends that were prevalent of the education at their time of inception. However, many critics believe that academies have failed to address these issues-increasing performance (Allen, Coldron and West, 2011) - and aggravated some-social segregation (Walford, 2014a). Rather than granting autonomy academies have increased accountability (Ranson, 2003; Curtis, 2009)allowing the state to be more influential while educators' roles were redefined and confined (Ranson, 2003; Wilkins, 2015). This created a quasi-market in education where competition, parents' choice, equity and individualism take precedence over equality, collectivism and social democracy.

The study aimed to discover how the administrators view the impacts of being an academy. Once issued governments are not keener on policy implementation as they 
are rarely monitored or evaluated for their outcomes. It is up to the school administrators to implement these policies at the school level (Levin, 2010). Again, not much of studies are conducted in this area except a survey conducted by the Department for Education [DfE] in 2014 regarding perceived impacts of academization. Therefore, the study conducting this research would be able to show how school administrators felt about the Academies Act.

\section{LITERATURE REVIEW}

\section{Controversies in Academies}

Academies have sparked opposition from many stakeholders (Hatcher, 2009). The contested areas of academies comprised of privatising schools, changing the characteristics of the schools, questioning the expertise of private sponsors on education and biased selection of students. Academies Act allowed the schools to independent of Local Education Authorities which paved the academies to explore new avenues in pedagogy, organizational structures, partnerships with the private sector, pay structure, hiring and firing of teachers, income generation, short-term contracts, alteration in catchment areas and budgeting (Armstrong Bunting and Larsen, 2009; Gunter, 2009)in order to increase their performance. It also facilitated the direct involvement of the government of school management to reframe the school education in a neo-liberal framework (Armstrong et al. , 2009) increasing upward accountability and decreasing downward accountability. Such autonomy hinders the autonomy for innovation (Fielding, 2001; Gleeson and Husbands, 2001) which the act was promised to grant to the academies and the administrators. The negative impacts of diminished downward accountability are witnessed as many academies are experiencing decrease performance, budget deficit, closures and some MATs are exploiting resources of academies (The Guardian, 2017a, 2017b; National Audit Office [NAO], 2010; Paton, 2014).

Furthermore, neo-liberal driven values and practices have changed the role of school administrators to act as managers rather than instructional leaders. The roles were redefined the professional identities by tilting the balance towards the organisation rather than the profession so that the public managers will manage the organizations as business-like (Stubbs, 2006). Sponsors have the authority to appoint the GB, leadership and management team of the academy who are aligned and immersed in their values (Gibson, 2015). The accountability of sponsors is also questioned regarding their motives and experience in the education field. Academy sponsors work as benefactors and sponsors while at the same time working as contractors, consultants and service providers to schools (Ball, 2011). Education offers a lucrative market for sponsors which is continuously expanding and thus sponsoring academies will allow them to build their image and learn about schools (Abrams, 2004; Hatcher, 2007) which will indirectly help them to increase their market share. Some academies are set up to disperse religious beliefs influencing curriculum and pedagogy (Harris and Burn, 2011). 
Although Academies were established to tackle social segregation they achieved the opposite creating a two-tier system - for rich and poor (BBC News, 2013). Both converter and sponsored academies with oversubscription can exclude with their oversubscription criteria or select $10 \%$ of the student intake based on the aptitude of students for certain subjects (Gorard, 2009; West, 2014). Over-subscribed academies can choose what type of students they want to admit to the school. These academies recruit better performing students to ensure their higher performance in the national assessments while turning down others who require more resources and psychic cost in staff (Levinson, Cookson and Sadovnik, 2002; Walford, 2014a). Segregation has negative impacts on students. Based on Brown vs. Board of Education (1954) it was argued that the segregation would deprive certain students of experiencing educational opportunities. Social mixing at school is beneficial for increasing student performance and building social cohesion (Glatter, 2011). This is evident upon examining the performance of PISA of different countries. The countries with comprehensive, uniform school systems outperformed countries like the UK where the education is much fragmented and diversified with a huge gap between high-performance students and low-performance students (ibid.). However, clustering similar students into the same schools may negatively impact on student attainments, motivation, selfbelonging, self-esteem and delinquency of students and strengthening social reproduction (Rumberger and Palardy, 2005).

Academies are established to increase the performance of disadvantaged students. However, these claims have been contested by both official and independent bodies (Gunter, 2011a). Longitudinal studies regarding the performance and Ofsted reports of academies have shown mixed results and some even requiring improvement and dysfunctional (Armstrong et al., 2009; Walford, 2014a). Thus, failing to reduce the gap between rich and poor student attainment (Whitty, 2008). The House of Commons Committee (2005) cautioned that the government should investigate the impacts of academies before it embarks on its application of academies countrywide. According to Curtis (2009), many academies failed to achieve the National Challenge benchmark set up by the government. Based on the 2003 PricewaterhouseCoopers [PwC] report, the first three city academies failed in increasing their performance and they have underperformed compared to their predecessor status (Taylor, 2005).

However, the increased performance of certain academies can be attributed to the following reasons: the improvements experienced across schools irrespective of academies, the reduction in Free School Meal [FSM] student intake, increased intake of non-FSM students and introduction of much easier General National Vocational Qualification [GNVQ] subjects (Gunter, 2011b; Machin and Wilson, 2009; Wrigley,2009; Wrigley, 2011). Therefore, there was no 'academy effect'. According to Titcombe (2008), academies are opting for GNVQ fourteen times higher than their predecessors thus boosting the performance of academies. However, this led to a watered-down curriculum in many subjects (Wrigley, 2011) questioning whether the employers will offer the same weight as the subjects offered in General Certificate of Secondary Education [GCSE] general curriculum in job prospects. 


\section{School Leadership}

The old form of bureaucratic authority has been challenged with managerialism, consumerism, public participation, competition and innovation. And it is important that the public managers are realigned with these neo-liberal concepts striking a balance between old form professionalism and market-driven managerialism (Newman and Clarke, 1997). Adopting managerialism allowed administrators to engage in innovation (Dunleavy and Hood, 1994). However, this is not the case. Employing such concepts will prevent innovation implemented at the grassroot level as they force to implement the structure of efficiency and measures of performance (Stubbs, 2006). Furthermore, managerialism redefined the professional identities by tilting the balance towards the organisation rather than the profession so that the public managers will manage the organizations as business-like (ibid.).

Neo-liberalism also forces the principals to higher accountability and scrutiny which will have negative impacts by creating low trust working environments, increased documentation and record-keeping, pressure towards achieving efficiency, intensification of duties and intrusion of generic managers to schools (Lingard, 1993; Rees and Rodley, 1995). Further, principals are compelled to engage in practices which are opposing in nature. For example, emphasising on performance management vs team building, market curriculum vs inclusive curriculum, and democratic practices vs school priorities such as increasing performances (Thomson, 2001). Neo-liberalism places the principals as technical and operational managers who simultaneously need to exercise social democracy. Their role is also confined and restricted in terms of curriculum, pedagogy, policymaking, innovation, cooperation, ethical obligations and controversies over cultural and social issues (ibid.). Although principals can rise above this neo-liberal framework it involves risk as it may seem like going against the state prescriptions. According to Bauman (1993), when stripped from morality, principals become faceless as it facilitates principals to adhere to standards and procedures depicted by the state allowing the state to easily control them. In Neo-liberalism, public ethics is a liability rather than a strength (Thompson and Riccucci, 1998).

However, these ethical characteristics may seem incompatible with the Neo-liberalism, thus leading to complexity and complications in discharging the duties. The conflict between professional values and neo-liberal values can be further explained by Hood's (1991) three types of administrative values which include Sigma-type, Theta-type and Lambda-type values. Sigma values relate to 'value for money' and efficiency which emphasise on output controls. These values resonate with neo-liberal values. Theta values involve honesty, fairness and mutuality while Lambda values involve reliability, stability and adaptability. I believe that these two value types are more in line with the Keynesian system which championed collectivism above all. Furthermore, all three value types cannot be satisfied without comprising the other two variables. For example, if the institution is more focused on sigma-type values then it might be difficult to achieve honesty and stability in the educational institution. 


\section{METHODOLOGY}

The study employed a case study to investigate the topic which is an interpretivist approach. The case study involves a detailed investigation into one setting or one specific phenomenon (Bogdon and Biklen, 1982). It focuses on an entity - a bounded system - which is a representative or atypical of the case (Burns, 1997) allowing the researcher to study the topic of interest in detail. Additionally, the case study offers a flexible and open-ended approach for data collection and analysis (Grinnell, 1981). Furthermore, a case study allows understanding human experiences which will result in explanation, evaluation or prescription of policies (Dopson, 2003). As the study intended to investigate the experience of school administrators regarding academization it was fitting to choose the case study for the research. Although in a case study, the findings cannot be generalised to a population my intention is to represent the case the academy - the researcher selected to investigate. However, generalisation can be obtained when the research resonates with the epistemology of the reader which she can relate to her own perceptions and experiences (Gomm, Hammersley and Foster,2000).

\section{Sample}

The academy the researcher selected is a secondary school before it was converted to an academy in 2014 (The Office for Standards in Education [Ofsted], 2014). It was a merger in 2011 of two secondary schools due to their low student enrolment and dilapidating building structure. According to the headteacher[HT] (2018), the merger was not well received by the parents of one school which performed well at the Ofsted reports while the other school had bad ratings. After the merger, the school failed to increase its performances requiring special measures and was forced to be an academy under a MAT.

The school is a typical case representing a sponsored academy located in a disadvantaged area. The catchment area of the academy includes 10\%-30\% low-income households (Poverty in City Name - an assessment of need, n.d.). According to Assistant Headteacher [AHT] (2018), most students came from working-class families.

The school has 1194 students with a capacity of 1350 and 73 academic staff (GetTheData, 2018). The academy has received the outcome in its latest Ofsted report as requires improvement in all the areas except sixth form programme being judged as Good (Ofsted, 2017). It has a below-average rating for Progress 8 score representing $18 \%$ of the schools in the UK. However, attainment 8 score for the academy is on par with the national level. Furthermore, the academy has similar ratings as the national ratings when considering achieving Grade 5 or above in English and Mathematics at GCSEs (Gov.uk, n.d.). However, this is markedly different when considering the disadvantaged pupils in the academy as they performed well below both at the local and national level in terms of GCSE $(\mathrm{O} / \mathrm{L})$ and Progress 8. At the GCSE $(\mathrm{A} / \mathrm{L})$ the academy progress was assigned as average. There is a higher proportion of students with SEN and health care plans compared to the national level (Ofsted, 2017). There are low levels of students whose first language is not English compared to national levels as most of 
Vol.8, Issue 2, pp.82-103, February 2020

Published by ECRTD- UK

Print ISSN: ISSN 2054-6351

Online ISSN: ISSN 2054-636X

the pupils are British White.13.7\% of the children are receiving FSM(GetTheData, 2018) and the national FSM is $12.4 \%$ for secondary schools (DfE, 2018).

\section{Semi-Structured Interviews}

Semi-structured interviews were utilized for data collection tool as they yield rich insights into participants' experience, opinion, values, aspirations, emotions and attitudes (May, 2011). They generally depict the questions. But the researcher can deviate from the questions based on the participants 'responses allowing both parties to enter a dialogue. They facilitate the people to answer more on their own terms simultaneously providing a structure to the interviews if the participants deviate too much from the intended goal of the interview (Wellington, 2005).

\section{Thematic Analysis (TA)}

Thematic analysis (TA) can be defined as identifying themes and patterns in the collected data set with respect to the research questions (Boyatzis, 1998). TA was used to identify themes in the research study, by employing both theory and research-driven to develop the themes from the interview transcriptions. In the theory-driven approach, themes emerge from the properties of the theory or theories the researcher has selected to explain the event. Research-driven themes are developed based on the findings of other researchers. Both these approaches allowed the researcher to develop or extend the knowledge based on theories and earlier research studies which according to Boyatzis not re-inventing the wheel. However, both approaches force the researcher to accept the assumptions and biases of the theories and researchers of the previous studies. Themes are not dependent on how many times the theme occurs in a data corpus. But it rather focuses on whether the data item has captured something significant in terms of the research questions which basically rely on the judgement of the researcher (ibid.).

In the analysis of data, the researcher followed Braun and Clarke (2006) step-by-step guide on doing thematic analysis and the following themes and sub-themes emerged from the data regarding the impacts of the changes.

- $\quad$ Impacts driven by Neo-liberal values

- Impacts driven by Keynesian values

- $\quad$ Leadership Impacts Vs Academy Chain Impacts

- $\quad$ Conflicts of values and ethics (See Figure 1.). 
Vol.8, Issue 2, pp.82-103, February 2020

Published by ECRTD- UK

Print ISSN: ISSN 2054-6351

Online ISSN: ISSN 2054-636X

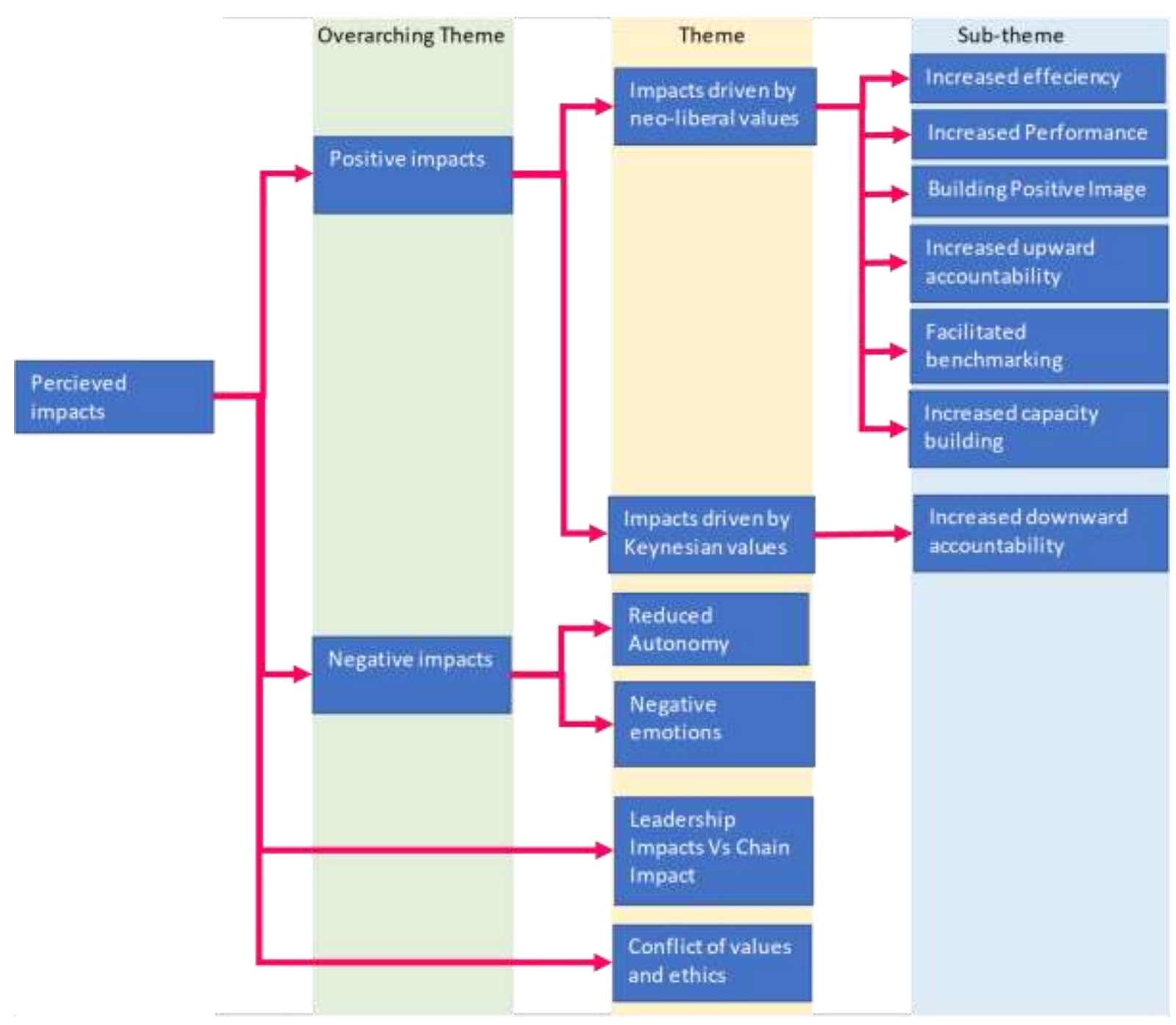

Figure 1. The Perceived Impacts of School Administrators

\section{DATA ANALYSIS AND DISCUSSION}

\section{Perceived Impacts}

Perceived impacts can vary by individual as perceptions are influenced by factors relating to the individual. These factors include attitudes, experience, motives, interests and expectations (citeman, 2008). Furthermore, the perception of certain impacts of the change may be quite different from when measured (Walker, Brewer, Boyne, and Avellaneda, 2011).

\section{Impacts driven by Neo-liberal values}

Implementing changes influenced by neo-liberal values increased efficiency, performance, standards, accountability and thus creating a positive image of the school. Increased efficiency

Efficiency can be defined as obtaining 'maximum output with minimum wasted effort' (Oxford, 2018). The HT restructured the staff converting the school from inefficient to 
efficient organization. He was also able to minimise the waste and eliminate the budget deficit by removing redundancies in the staff and restructuring it.

There was a budget deficit of 800000 pounds... The budget for the school was 7 million pounds. So to be spending $10 \%$ more than $10 \%$ of your budget overspending is bad... so I restructured so that it saved us 800000 pounds. (HT, 2018).

According to AHT (2018), the school being in an academy chain has been able to increase its efficiency in terms of two aspects: financial and academic.

Financial efficiency is obtained through centralising certain services and roles of the academy chain through resource sharing. According to AHT (2018), the financial efficiency is gained by appointing a single person and services for the three academies in HR, finance, timetable, data management and catering services thus allowing the school to recruit supporting teaching staff. One of the strategies to increase efficiency in academies is to reduce the staffing cost as $80 \%$ of the school budget is allocated for staff salary (Harden, 2015).

Additionally, AHT expressed that developing the curriculum through collaboration between the other two academies also contributed to lessening the workload of teachers and thus improving efficiency. In a survey conducted by DfE in 2017 found that $88 \%$, $84 \%, 71 \%, 71 \%$ and $54 \%$ of MATs achieved efficiency in terms of financial, HR, ICT solutions, curriculum and catering.

However, it should be noted that many academies have experienced budget deficits due to overstaffing, fraud, higher salaries to top management (The Guardian, 2017b, 2011; Owen, 2017). This may since many academies are lacking adequate financial controls to ensure proper use of financial resources (www.parliament.uk, 2011). And it was recommended by the Public Accounts Committee that the DfE and the YPLA should enforce strict financial regulations on academies.

\section{Increased Performance in Academy}

The main reason for the school to be converted to an academy was to increase its performance. According to a survey conducted by DfE (2014), two-thirds of the academies claimed that the conversion had increased the student attainment. According to HT (2018), he has increased the performance of the school since he assumed duties as the headteacher.

I can quantify the improvement in terms of results... Indicators to show that the school has improved. The school has almost certainly has improved.

However, the AHT expressed a different perception regarding the performance of the school in terms of inspection and national assessment at Key Stage [KS] 5.

We've been part of Twain Academy School Trust for 4 years now. We are requiring improvement. We were four. Now we are 3. We've improved. But we are not 2 or 1. (AHT, 2018)

There is no evidence, yet this academy has improved results for the school. It doesn't. our results were worse than the previous year... the end results for the last 4 years have gone up. Last year it dipped a little bit.

(AHT, 2018) 
These two statements, however, corroborates with the facts presented in the Literature Review as there is no inconclusive evidence that the academies have increased performance. According to Gorard (2011), much of the claims of increased performance have been attributed to reducing the intake of FSM students. However, the HT denies any student from being expelled or denied entry into the school in the hopes of increasing the performance of the school.

For some trusts, they bring about exclusion. They exclude a lot of kids. We don't... So, an academy in pursuit of results looking to show how to bring about improvement who got rid of all the naughty kids. the kids who are not going to achieve.

(HT, 2018)

\section{Building a positive image}

Predecessor status of sponsored academies is expected for their lower expectations, aspirations and opportunities for their communities. The national discourses surrounding the academies are formulated as such that they will provide remedies for the problems mentioned above (Purcell, 2011). Academies were considered as a magic bullet for all the ills facing underperforming schools. Such notions of perceptions and the changes which initiated to address lower expectations, aspirations and opportunities with the conversion to academy status allowed the school to reinvent itself. Changes such as restructuring staff, the introduction of uniform, behavioural policy and code of conduct and participatory decision making allowed the HT to change the school environment and build a better public relation (PR) with the community.

With the changes initiated the school was able to change the perception of the community it served. Having built a positive image of the school allowed the school to experience positive impacts. According to HT:

$86 \%$ of parents would recommend us to another parent... There is a greater reputation. We used to struggle to recruit that would perhaps 180 in a year group. We now have 250 joining our current year of serving. We have a waiting list. That's brought about our finances. (HT, 2018)

\section{Increased upward accountability}

Accountability can be defined as being responsible for one's own actions. However, exercising too much accountability is never criticised as there is always pressure for increased accountability from the top (Charlton, 2002). Having increased upward accountability means that school leaders and teachers must adhere to performance measurements, appraisals and job descriptions.

And everybody's performance is managed and appraised. I am accountable for the last school performance. ... And I am set to see as managing performing targets. I have to demonstrate at the meetings. if I don't meet then there's discretion about my performance. (HT, 2018)

\section{Facilitated benchmarking in the Academy chain}

Benchmarking can be defined as the technique used to recognise best practices that are implemented by other organizations (Baker, 2007). Thus, allowing the organization to 
Vol.8, Issue 2, pp.82-103, February 2020

Published by ECRTD- UK

Print ISSN: ISSN 2054-6351

Online ISSN: ISSN 2054-636X

implement those practices to improve themselves. It also helps to identify areas that need improvement (Gunasekaran, 2005). Working as an academy in a chain allowed the school to identify and benchmark practices regarding pedagogy and assessments. Currently, the academy has benchmarked its pedagogy and assessment in Mathematics, Science, Geography and English and is looking towards benchmarking Technology. Furthermore, this process has been facilitated by implementing the centralised MIT allowing senior school leaders to assess performance across the chain to identify best practices.

However, it was felt that rather than pedagogy being benchmarked it has been colonised. Although the colonization of curriculum has occurred at the national level through reforms as indicated by Braun, Maguire and Ball (2010) it can be identified that the colonisation is occurring at the local level in MATs where the curriculum of the hub academy is applied without any modification. However, the Twain academy is markedly different from the Harper academy having majority students from middleclass and 'outstanding performance' from the Ofsted reports. And the pedagogy and the assessments in hub academy may reflect values, beliefs and ethos that suit and reflect middle-class which might not be suitable for the Harper academy and have negative impacts on the school. Furthermore, it undermines the values and ethos of the school and the stakeholders and suggests that to increase performance the school must adopt the procedures that are operated in the hub academy which are designed for middleclass students.

\section{Increased capacity building}

Building capacity of the staff has occurred in two phases. The first phased involved training due to establishing the centralised MIS and professional development with appraisal goals and targets. The second phase involved the collaboration of the three schools in which middle management are to share experience, expertise and resources to develop the subject curriculum. According to AHT (2018), such collaboration has allowed him to work in a strategic role - English Leader - rather than in an operational role.

Irrespective of school is an academy or not inter-school collaboration facilitates teacher learning, provide opportunities to consult problems and find solutions together and build confidence and motivate the staff (Ainscow and Howes, 2006; Ainscow, Muijs and West, 2006). Reviewing eleven case studies West (2010) discovered that collaboration had a high positive impact on teachers' knowledge and skills on teachinglearning, behavioural changes and classroom management. Thus, ultimately leading to improved teaching-learning process and increased the performance of the school. Although this new role is an additional responsibility, the AHT was enthusiastic about his role contributing to impact positively on the three schools in the chain. This is also known as distributed leadership (West, 2010) or system leadership (Gibson, 2018) in which leadership is spread across the chain. 


\section{Impacts driven by Keynesian values}

These impacts involve increasing social justice and equality in the community. In terms of the academy, this means increasing downward accountability.

\section{Increased downward accountability}

One of the objectives of academization is to achieve social justice by becoming more accountable to the community it is serving through community engagement and increasing the performance of students from disadvantaged backgrounds. However, according to the recent report by the House of Commons Education Committee (2018), the MATs have achieved the opposite. It was felt by parents that many MATs have disengaged and disconnected from the communities. Furthermore, the report indicates MATs have increased upward accountability rather than downward accountability.

Although the AHT agreed that being an academy has not increased its capacity to address social disadvantage the school leadership has taken the initiative to address it through the changes mentioned previously.

But I don't necessarily think because of the academy but I think it's because of effective leadership in the school. It's been only 12 months we have actually started to act as one organization together. So the improvements thus far have been due to the strong leadership of the school. Not through trust (AHT, 2018).

Although statistically, the impact of the school on disadvantaged pupils is small compared to the family (Rogers, 2017) coupled with the low attendance rate of these students, the school has been able to increase the performance of the students who attend school regularly. Furthermore, the school has also taken measures to improve its relationship with the community, especially with disadvantaged families.

we always proactively work with parents...I mean as an example we met with the families of disadvantaged children this year and we just ask them if there's anything that we could do to improve their life at school and to improve the relationship with the family in the school(AHT, 2018).

\section{Negative impacts}

\section{Reduced autonomy}

One of the objectives of converting to an academy is to grant autonomy to school leaders so that they can engage in innovation to uplift the performance of the school. However, many critics proved the contrary. A research conducted by the London School of Economics and Political Science (LSE) showed that more than $70 \%$ of the academies in MATs having less freedom as compared to their predecessor status under LEAs.

Both AHT and HT agreed that there is less autonomy in the school. Autonomy is compromised at two levels: being an academy and being in a chain. According to AHT the school converted to an academy altered the autonomy it was experiencing prior to the conversion.

... If you ask the headteacher that I think he would be rather frustrated. Because his decisions are significantly eroded. His power in the school is not gone.... he has become 
Vol.8, Issue 2, pp.82-103, February 2020

Published by ECRTD- UK

Print ISSN: ISSN 2054-6351

Online ISSN: ISSN 2054-636X

a less strategic leader in the school. Now he's got the CEO, the headteacher, Trust board above him (AHT, 2018).

Autonomy was further reduced when the academy started operating to be aligned with the academy trust. Many services and curriculum are centralised.

We are losing autonomy because certain decisions are not made by us anymore. for example, the timetable is not done by us... so we have without a doubt there's less autonomy. (AHT, 2018)

However, the HT expressed his acceptance of reduced autonomy for more positive impacts of being in an academy trust through collaboration and resource sharing.

I might not have a say in what is tested in year 9. But if I can gain an insight as to how my school perform against other schools I think it's very useful information. So, autonomy you can say that there is an erosion of autonomy. But it also allowed us to establish what best practice is.

(HT, 2018)

\section{Experiencing negative emotions}

Changes cause negative emotions which include stress, worry, confusion, exhaustion and fear. Although the AHT expressed his satisfaction with his additional responsibility collaborating with others in the chain while the HT expressed something quite different stating that his role has been so far isolating.

It can be isolating being the headteacher. Very lonely... Who do I go to say that I am struggling? Who do I go to if I find this particular part of the school difficult to bring about change? Who do I go to say give me advice? Who do I go to when I am stressed, and I am struggling? And it's for senior leaders as well. So, it can be a lonely job. bringing something to deliver that's not popular. So, it can be a very isolating job (HT, 2018). A study was conducted in Chile regarding experiences of novice principles in failing schools serving highly disadvantaged communities. The schools recognised as sinking shared many similarities with the Harper school (Galdames, Montecinos, Campos, Ahumada, and Leiva, 2017). The principals felt they were alone during the change process as there was no support from the staff and the municipal departments of education.

\section{Leadership Impacts Vs Academy Chain Impacts}

The following Table 4.1 summarises the impacts of the changes that took place in the academy due to changes implemented by the leadership and by the academy chain. 
Table 4.1: Leadership Impacts Vs Academy Chain Impacts

\begin{tabular}{|l|l|}
\hline Leadership Impacts & Academy chain Impacts \\
\hline Increased financial efficiency & Increased efficiency \\
\hline Increased performance & Increased capacity building \\
\hline Building a positive image & \\
\hline Increased capacity building & \\
\hline Increased upward accountability & \\
\hline Increased downward accountability & \\
\hline
\end{tabular}

Analysing the impacts, it can be stated that the leadership of the school had more impact compared to school being in an academy chain. However, this interpretation should be considered with two factors: the impacts listed here are perceived impacts therefore and might not be the impacts experienced by the school, and according to AHT (2018), the academy chain-wide changes occurred since last year and therefore had limited time for change implementation.

However, it should be noted that effective leadership is an essential component of raising the underperforming schools. Many studies conducted on effective leadership have proven that leadership play an important role in increasing student performance irrespective of the context of the school (Barber, Whelan, and Clark, 2010; Martorell, Heaton, Gates, and Hamilton, 2010).

According to AHT (2018), the improvements so far achieved uplifting the disadvantaged pupils were credited to school leadership. Furthermore, HT (2018) stated that being an academy has neither increased student performance nor helped him to serve as the headteacher in the school. The only positive impacts of being in an academy are through collaboration within the academy chain. However, it is not a unique characteristic of academy chains. There are many collaborations that are operating between GM schools and LEA representatives which provide resource sharing and capacity development for the staff. They include formal collaborations, federations, amalgamations (Anonymous, 2017) and proved positive results on student achievements (Ainscow and Howes, 2006).

So, analysing the interview data, it seems as there is no 'academic effect' offered by academization which is also confirmed by HT and AHT. According to the NAO report in 2018 converting schools to academies have cost the government $£ 745$ million since 2010 (George, 2018). Furthermore, prior to their conversion, the former heads stated what the school needed was investment and revitalisation (Gunter and McGinity, 2014). Rather than turning underperforming schools to academies, the effort and resources could have been diverted to changing and developing leadership and providing additional resources to them.

\section{Conflicts of values and ethics}

Both individual and group decisions are influenced by values (Hughes, Rao, and Akler, 1976). Values guide people's actions, behaviours and judgements (Beatty, Kahle, 
Vol.8, Issue 2, pp.82-103, February 2020

Published by ECRTD- UK

Print ISSN: ISSN 2054-6351

Online ISSN: ISSN 2054-636X

Homer, and Misra, 1985). Therefore, the decisions on what changes to implement depend on the values of the individuals who are implementing them. According to Hood (1991), there are three types of administrative values: Sigma, Theta and Lambda. The changes and impacts initiated by the leadership can be attributed to sigma, theta and lambda values. And the trust initiated-changes can be attributed to sigma values. Therefore, it can be stated that the values of school administrators in the academy are influenced by both neo-liberal and Keynesian values while academy trust is influenced by neo-liberal values.

It is evident that both AHT and HT while aiming to achieve efficiency and performance that they are committed to achieving social justice for the community it is severing.

...in order to close the gap in performance, you have to do something deliberate and to improve the pace of disadvantaged children because if everyone approves the gap improves. You've got to do something that closes the gap. Disadvantaged children have to make a faster rate of progress than others (AHT, 2018).

...I could have done things quicker by excluding children. All in all, let's get rid of them. That's not right by the community we serve. schools that exclude in higher rate is not serving its community (HT, 2018).

However, the HT also expressed his concerns on staff and pupils' well-being over pursuing efficiency and performance implying that there may be a compromise of theta and lambda values — Keynesian values.

...I would say that there has been.... it does take out on my senior leaders. It does affect their wellbeing. The long hours. Stress. It does affect their health... People left school because they weren't doing the job. it affected their livelihood and affects their family (HT, 2018).

Sometimes wonder if we put too much stress on pupils. And the impact is having all the expectations stress we put on them the demands we put on the children to get good grades is that some way of robbing of them their childhood (HT, 2018).

According to Bell and Stevenson (2006) when the role of headteacher converted from welfarist to a manager then the educational values are forfeited for performance and efficiency. These collisions often lead to ethical dilemmas, struggles, negotiations and compromises. But according to Wright (2001), due to strong external influences such as accountability, forces the school leaders to adhere to neo-liberal values at the expense of Keynesian values. However, effective leadership can strike a balance between both these extremes trying to achieve both values (Bell and Stevenson, 2015). According to Hood's three types of administrative values, placing one value type at the centre may constrain achieving the other two value types. So, in academization emphasising more on performance and efficiency may lead to achieving fewer opportunities to achieve social justice and security which can be attributed to the concerns of the HT expressed mentioned previously. 


\section{Key Findings}

Perceived impacts reflect the neo-liberal and Keynesian values of school leadership. However, implementing changes driven by neo-liberal values seems to have come to conflict with the Keynesian and ethical values of the school leaders especially regarding the headteacher. Although they try to balance between the two types of values neoliberal values seems to have dominated their decision-making process due to external accountability structures imposed by the government. Moreover, the school administration also doubts that the academization had a positive impact on school performance but rather attribute the success they gained so far as a school is due to its leadership. It is therefore crucial that introducing innovative governing structures must be carefully studied and monitored not to constrain school administrators but to empower and facilitate them as the success of the academies or schools are dependent on the leadership skills of the school administrators.

\section{Limitations}

The main obstacle I faced during the research was recruiting academies to participate in the research. My initial objective was to conduct the research covering five academies interviewing at least two members from the school senior management team. Only one academy responded to me positively therefore, I had to redesign my research to reflect the case study to only include one school.

Another limitation was that I could not decide the place and time of the interviews. I had to reschedule the interview with the headteacher thrice. Additionally, I conducted the interviews at the school and therefore were subjected to interruptions. And the interviews were scheduled in late afternoons may have also affected the responses of the participants due to fatigue and exhaustion after their days work at school. I was also unable to schedule any follow-up interviews with the two participants which would have enabled me to clarify any doubts regarding the content of the first interviews with them and to gain better understand the perception of the academization of school administrators.

\section{Future Research}

Reflecting on the findings I think there are many possibilities for future research with respect to the Academies Act. The following are such three possibilities.

One research possibility is examining the experiences of senior management in implementing the academies act. As the HT expressed his lack of support during the changes a study involving many school leaders to examine the 'professional isolation' of them during changes may give more insight into this phenomenon. It is also possible to study the experience of middle managers - Assistant Headteachers - as the academization has positive impacts on AHT's role in this case study.

Another research possibility is to conduct the same research in a converter academy where the perception of administrators might be different from the sponsored academy or obtaining a bigger sample.

The final possibility of research is the colonisation of culture or acculturation occurring especially in sponsored academies by the hub academy. This colonization may occur in 
Vol.8, Issue 2, pp.82-103, February 2020

Published by ECRTD- UK

Print ISSN: ISSN 2054-6351

Online ISSN: ISSN 2054-636X

the form of curriculum, teaching methods and training and development of staff. However, there are no studies that are conducted about acculturation in sponsored academies. It is interesting to see to what extent this phenomenon occurs across the academies replacing the values and beliefs of working-class families with the beliefs and values of middle-class families.

\section{References}

1. Abrams, F. (2004). Take my advice. Times Educational Supplement, May 14: $8-9$.

2. Ainscow M., and Howes A. (2006). Working together to improve urban secondary schools: a study of practice in one city Retrieved March 28, 2018, https://www.tandfonline.com/doi/full/10.1080/13632430701379578

3. Ainscow, M., Muijs, D., and West, M. (2006). Collaboration as a strategy for improving schools in challenging circumstances Paper prepared for 'Improving Schools'. Retrieved June 7, 2018, https://www.humanities.manchester.ac.uk/.../paper_for_improving_schools_july_06.

4. Allen, R., Coldron, J., and West, A. (2011). The effect of changes in published secondary school admissions on pupil composition, Journal of Education Policy, 27(3), 349-366. DOI: 10.1080/02680939.2011.604137

5. Anonymous. (2017). Surrey Education in Partnership: Partnership models for schools. Retrieved July 11, 2018, https://www.surreycc.gov.uk/_data/assets/pdf_file/0004/118246/Education-in-

Partnership-Partnership-Models-for-Schools-v2.pdf

6. Armstrong, D., Bunting, V., and Larsen, J. (2009).Academies: a model for school improvement? Key findings from a five-year longitudinal evaluation. Management in Education, 23(3), 118-124. https://doiorg.sheffield.idm.oclc.org/10.1177/0892020609105805

7. Assistant Headteacher [AHT]. (2018, June 18). Personal interview

8. Ball, S. J. (2011). Academies, policy and governance the state and education policy. In: H. M. Gunter (Ed.), The state and education policy: Academies Programme, (pp. 146-158). New York: Continuum International Publishing Group

9. Barber, M., Whelan, F., and Clark, M. (2010). Capturing the leadership premium: How the world's top school systems are building leadership capacity for the future. Retrieved March 8, 2018, http://mckinseyonsociety.com/downloads/reports/Education/schoolleadership_final.pd $\mathrm{f}$

10. Barker, B. (2007). The leadership paradox: Can school leaders transform student outcomes? School Effectiveness and School Improvement, 18(1), 21-24.

11. Bauman, Z. (1993) Postmodern Ethics. Oxford: Blackwell.

12. BBC News. (2013).Academies could 'fuel social segregation. Retrieved March '8, 2018, https://www.bbc.com/news/education-20960500

13. Beatty, S.E., Kahle L.R., Homer, P., and Misra, S. (1985). Alternative Measurement Approaches to ConsumerValues: The List of Values and the Rokeach Value Survey. Psychology \& Marketing, 2(3),181-200. 
Vol.8, Issue 2, pp.82-103, February 2020

Published by ECRTD- UK

Print ISSN: ISSN 2054-6351

Online ISSN: ISSN 2054-636X

14. Bell, L., and Stevenson, H. (2006). Education Policy Process, Themes and Impact. New York: Routledge

15. Bell, L., and Stevenson, H. (2015). Towards an analysis of the policies that shape public education. Management in Education, 29(4), 146-150. DOI: $10.1177 / 0892020614555593$

16. Bogdan, R. C., and Biklen, S. K. (1982). Qualitative research for education: An introduction to theory and methods. Boston: Allyn and Bacon.

17. Boyatzis, R. E. (1998). Thematic Analysis and Code Development Transforming Qualitative Information. California: Sage

18. Braun, A., Maguire, M., and Ball, S. J. (2010). Policy Enactments in the UK Secondary School: Examining Policy, Practice and School Positioning. Journal of Education Policy, 25(4), 547-560

19. Braun, V., and Clarke, V. (2006) Using thematic analysis in psychology, Qualitative Research in Psychology, 3(2), 77-101.DOI: 10.1191/1478088706qp063oa 20. Brown vs. Board of Education, (1954). Retrieved March 8, 2018, http://www.nationalcenter.org/brown.html

21. Burns, R. B.(1997). Introduction to Research Methods (2nd ed.). Melbourne: Longman Cheshire

22. Burns, R.B. (1997). Introduction to Research Methods (3rd ed.). South Melbourne: Addison Wesley Longman Australia

23. Charlton, B. G. (2002). Audit, Accountability, Quality, and All That: The Growth of Managerial Technologies in UK Universities. Retrieved July 11, 2018, https://www.hedweb.com/bgcharlton/audit.html

24. citeman. (2008). Factors Influencing Perception. Retrieved March 8, 2018, https://www.citeman.com/2849-factors-influencing-perception.html

25. Cookson, D. L. P. W., and Sadovnik, A. R. (2002). Education and Sociology Levinson Retrieved March 8, 2018, https://books.google.co.uk/books?id=gcelAgAAQBAJ\&pg=PA477\&lpg=PA477\&dq $=$ oversubscribed+schools+attracting+high+end+clientele\&source $=$ bl\&ots $=1$ O0jbhTK Wp\&sig=13DzYxi82T9CZGoz2r1GDvxC8U0\&hl=en\&sa=X\&ved=2ahUKEwjG89G OydXcAhUoC8AKHcN2DQIQ6AEwA3oECAcQAQ\#v=onepage\&q=oversubscribed $\% 20$ schools $\% 20$ attracting\%20high $\% 20$ end $\% 20$ clientele $\& \mathrm{f}=$ false

26. Curtis, A. (2009). Academies and school diversity. Management in Education, 23 (3), 113-117.https://doi-org.sheffield.idm.oclc.org/10.1177/0892020609105804

27. Department for Education [DfE]. (2014). Do academies make use of their autonomy? Research report. Retrieved March 8, 2018, https://assets.publishing.service.gov.uk/government/uploads/system/uploads/attachme nt_data/file/401455/RR366_-_research_report_academy_autonomy.pdf

28. DfE. (2017). Academy trust survey: 2017 Research report. Retrieved March 8, 2018 ,

https://assets.publishing.service.gov.uk/government/uploads/system/uploads/attachme nt_data/file/629779/Academy_Trust_Survey_2017.pdf

29. DfE. (2018). Schools, pupils and their characteristics: January 2018.Retrieved March 8, 2018, https://assets.publishing.service.gov.uk/government/uploads/system/uploads/attachme nt_data/file/719226/Schools_Pupils_and_their_Characteristics_2018_Main_Text.pdf 
Vol.8, Issue 2, pp.82-103, February 2020

Published by ECRTD- UK

Print ISSN: ISSN 2054-6351

Online ISSN: ISSN 2054-636X

30. Dopson, S. (2003). Potential of the case study method for organizational analysis. policy and politics,31(2), 217-226

31. Dunleavy, P. and Hood, C. (1994). From Old Public Administration to New Public Management. Public Money \& Management, 14(3), 9-16.

32. Fielding, M. (2001). Taking Education Really Seriously: Four Years Hard Labour, London: Routledge Falmer

33. Galdames, S., Montecinos, C., Campos, F., Ahumada, L., and Leiva, V. M.(2017). Novice principals in Chile mobilizing change for the first time: Challenges and opportunities associated with a school's readiness for change. Educational Management Administration \& Leadership, 46(2), 318-338. https://doiorg.sheffield.idm.oclc.org/10.1177/1741143217707520

34. George, M. (2018). DfE fails to run 'fit and proper' checks on all academy leaders. Retrieved March 8, 2018, https://www.tes.com/news/dfe-fails-run-fit-andproper-checks-all-academy-leaders

35. GetTheData, (2018). Academy Name data. Retrieved March 8, 2018,https://www.getthedata.com/school/ school

36. Gibson, M.T. (2015). Ethos and vision realization in sponsored academy schools. Management in Education, 29 (1), 9-13. https://doiorg.sheffield.idm.oclc.org/10.1177/0892020614559237

37. Gibson, M.T. (2018). Leadership preparation and development within a multiacademy trust. Management in Education, 32(2), 92-97. DOI: $10.1177 / 0892020618762716$

38. Glatter, R. (2011). Joining up the dots: Academies and system coherence. In: H. M. Gunter (Ed.). The state and education policy: Academies Programme, (pp. 39-51). New York: Continuum International Publishing Group

39. Gleeson, D., and Husbands, C. (2010). Modernizing schooling through performance management: a critical appraisal, Journal of Education Policy, 18(5), 499511, DOI: $10.1080 / 0268093032000124866$

40. Gomm, R., Hammersley, M., and Foster, P. (2000). Case Study and Generalization. In: R. Gomm, M. Hammersley and P. Foster (Eds.). Case Study Methods: Key Issues Key Texts, (pp.98-112). London: Sage

41. Gorard, S. (2009). Serious doubts about school effectiveness, British Educational Research Journal, 36:5, 745-766, DOI: 10.1080/01411920903144251

42. Gorard, S. (2011). Measuring segregation - beware of the cautionary tale by Johnston and Jones. Environment and Planning,43(1), 3-7.

43. Gorard, S. (2014). The link between Academies in England, pupil outcomes and local patterns of socio-economic segregation between schools, Research Papers in Education, 29(3), 268-284, DOI: 10.1080/02671522.2014.885726

44. Gov.uk. com. (n.d.). Poverty in City Name. Retrieved March 8, 2018, https://www.compare-school-

performance.service.gov.uk/school/140547democracy.cityname.gov.uk/documents/.../ Tackling\%20Poverty\%20Strategy\%202.pdf

45. Grinnell, R. J. (1981). Social work research and evaluation. Itasca, IL: F.E. Peacock.

46. Gunasekaran, A. (2005). Benchmarking in public sector organizations, Benchmarking: An International Journal, 12(4). DOI: 10.1108/bij.2005.13112daa.001 
Vol.8, Issue 2, pp.82-103, February 2020

Published by ECRTD- UK

Print ISSN: ISSN 2054-6351

Online ISSN: ISSN 2054-636X

47. Gunter, H. M. (2009). Radical reforms: perspectives on an era of educational change. London: Routledge

48. Gunter, H. M., and McGinity, R. (2014). The politics of the Academies Programme: natality and pluralism in education policy-making, Research Papers in Education, 29:3, 300-314, DOI: 10.1080/02671522.2014.885730

49. Gunter, H.M. (2011a). Conclusion: Public Education and Academies. In: H. M. Gunter (Ed.), The state and education policy: Academies Programme, (pp. 212-233). New York: Continuum International Publishing Group

50. Gunter, H.M. (2011b). Introduction: Contested Educational Reforms. The state and education policy: Academies Programme, (pp. 1-18). New York: Continuum International Publishing Group

51. Harnden, J. (2015). Improving financial efficiency for academies Retrieved March 28, 2018, https://www.capita-sims.co.uk/resources/blog/improving-financialefficiency-for-academies

52. Harris, R., and Burn, K. (2011). Curriculum theory, curriculum policy and the problem of ill-disciplined thinking, Journal of Education Policy, 26(2), 245-261, DOI: 10.1080/02680939.2010.498902

53. Hatcher, R. (2007). Privatization and sponsorship: the re-agenting of the school system in England, Journal of Education Policy, 21(5), 599-619, DOI: 10.1080/02680930600866199

54. Hatcher, R. (2009). Setting up Academies, campaigning against them an analysis of a contested policy process. Management in Education, 23 (3), 108-112. https://doi-org.sheffield.idm.oclc.org/10.1177/0892020609105803Richard Hatcher

55. Headteacher [HT]. (2018, June 25). Personal interview

56. Hood, C. (1991). A public management for all seasons? Public Administration, 69 (1): 3-19.

57. House of Commons Committee of Public Accounts. Academy schools' finances. Thirtieth Report of Session 2017-19. (2018). Retrieved March 8, 2018, https://publications.parliament.uk/pa/cm201719/cmselect/cmpubacc/760/760.pdf

58. House of Commons. (2005) Education and Skills Committee: Secondary Education. Fifth Report of Session 2004-05. London: The Stationery Office

59. Hughes, D., Rao, V.R., and Akler, H.A. (1976). The influence of values, information and decision orders on a public policy decision. Journal of Applied Social Psychology, 6, 145-148

60. Levin, B. (2010). Governments and education reform: some lessons from the last 50 years. Journal of Education Policy, 25(6), p.739-747.

61. Lingard, B. (1993). Corporate federalism: the emerging approach to policymaking for Australian schools, In: B. Lingard, J. Knight and P. Porter (Eds.), Schooling Reform in Hard Times, (24-35). London: Falmer Press

62. London School of Economics and Political Science [LSE]. (2018). Academisation of state education has reduced freedom and autonomy for schools. Retrieved Juneb8, 2018, http://www.lse.ac.uk/News/Latest-news-fromLSE/2018/06-June-2018/Academisation-of-state-education-has-reduced-freedom-andautonomy-for-schools

63. Machin, S., and Wilson. J. (2009). Academy schools and pupil performance. Centrepiece, 14(1), 6-8 
Vol.8, Issue 2, pp.82-103, February 2020

Published by ECRTD- UK

Print ISSN: ISSN 2054-6351

Online ISSN: ISSN 2054-636X

64. Martorell, F., Heaton, P., Gates, S. M., and Hamilton, L. S. (2010). Preliminary findings from the new leaders for new school's evaluation. Retrieved 8 March, 2018, http://

www.rand.org/content/dam/rand/pubs/working_papers/2010/RAND_WR739.pdf

65. May, T. (2011). Social research (4th ed.). Maidenhead: Open University Press

66. National Audit Office [NAO]. (2010). The Academies Programme. Retrieved

March 8, 2018, https://www.nao.org.uk/report/department-for-education-theacademies-programme/

67. Newman, J., and Clarke, J. (1997). The Managerial State: Power, Politics and Ideology in the Remaking of Social Welfare. London: Sage

68. Ofsted. (2017). Ofsted School Name. Retrieved July 8, 2018, https://reports.ofsted.gov.uk/inspection-reports/find-inspection-report/provider/ELS/

69. Owen, J. (2017). Exclusive: Top-earning academy bosses revealed. Retrieved March 5, 2018, https://www.tes.com/news/exclusive-top-earning-academy-bossesrevealed

70. Oxford Dictionary. (2018). efficiency. Retrieved March 8, 2018, https://en.oxforddictionaries.com/definition/efficient

71. Paton, G. (2014). DfE bars 14 academy chains from taking on more schools. Retrieved March 8, 2018, https://www.telegraph.co.uk/education/educationnews/10709227/DfE-bars-14-

academy-chains-from-taking-on-more-schools.html

72. Poverty in City Name - an assessment of need. (n.d.). Tackling Poverty Strategy. $\quad$ Retrieved March 8, 2018, http://democracy.cityname.gov.uk/documents/s17338/Tackling\%20Poverty\%20Strate gy\%202.pdf

73. Purcell, K. (2011). Discourses of aspiration, opportunity and attainment: promoting and contesting the Academy schools programme, Children's Geographies, 9(1), 49-61, DOI: 10.1080/14733285.2011.540439

74. Ranson, S. (2003). Public accountability in the age of neo-liberal governance. Journal of Education Policy, 18(5), 459480. DOI: $10.1080 / 0268093032000124848$

75. Rees, S., and Rodley, G. (1995): The human costs of managerialism: Advocating the recovery of humanity. Sydney: Pluto Press Australia

76. Rogers, T. (2017). Teachers can only ever have a small impact on their students' results - yet they are judged as if they are 100\% responsible. Retrieved March 8, 2018, https://www.tes.com/news/teachers-can-only-ever-have-small-impact-their-studentsresults-yet-they-are-judged-if-they-are-100\%-responsible

77. Rumberger, R.W. And. Palardy, G. J. (2005). Does Segregation Still Matter? The Impact of Student Composition on Academic Achievement in High School. Teachers College Record ,107(9), 1999-2045. Retrieved from https://secure.edweek.org/media/does_segregation_still_matter.pdf

78. Stubbs, R. (2005).Political Economy and the Changing Global Order (3rd ed.).Oxford: University Press Oxford

79. Taylor, M. (2005). private academy produces worse results than the schools it replaced. Guardian 19 May 
Vol.8, Issue 2, pp.82-103, February 2020

Published by ECRTD- UK

Print ISSN: ISSN 2054-6351

Online ISSN: ISSN 2054-636X

80. The Guardian. (2011). Too many senior staff in academies? Retrieved March 8, 2018, https://www.theguardian.com/education/2011/nov/14/academies-seniormanagement-salaries-taxpayers

81. The Guardian. (2017a). 40,000 children trapped in 'zombie' academy schools. Retrieved March 8, 2018, https://www.theguardian.com/education/2017/dec/03/thousand-pupils-trapped-inzombie-academy-schools

82. The Guardian. (2017b). Collapsing academy trust 'asset-stripped its schools of millions. $\quad$ Retrieved March 8, 2018, https://www.theguardian.com/education/2017/oct/21/collapsing-wakefield-cityacademies-trust-asset-stripped-schools-millions-say-furious-parents

83. The Office for Standards in Education [Ofsted]. (2014). Ofsted School Name.Retrieved March 8, 2018. https://reports.ofsted.gov.uk/inspection-reports/findinspection-report/provider/ELS/

84. Thompson, F.J. and Riccucci, N.M. (1998), 'Reinventing government'. Annual Review of Political Science, 1, 231-257

85. Thomson, P. (2001). How Principals Lose 'Face': A disciplinary tale of educational administration and modern managerialism, Discourse: Studies in the Cultural Politics of Education, 22(1), 5-22, DOI: 10.1080/01596300120039722

86. Titcombe, R. (2008). how academies threaten the comprehensive curriculum? forum. $\quad$ Retrieved March 8, 2018, www.wwwords.co.uk/rss/abstract.asp?j=forum\&aid=3194

87. Walford, G. (2014b). Academies, free schools and social justice, Research Papers in Education, 29(3), 263-267. DOI: 10.1080/02671522.2014.885725

88. Walford, G. (2014a). From city technology colleges to free schools: sponsoring new schools in England, Research Papers in Education, 29(3), 315329. DOI: $10.1080 / 02671522.2014 .885731$

89. Walker, R. M., Brewer, G. A., Boyne, G. A., and Avellaneda, C. N. (2011). Market Orientation and Public Service Performance: New Public Management Gone Mad? Public Administration Review, 71(5), 707-717. doi:10.1111/j.1540-6210.2011. 02410.x

90. Wellington, J. J. (2015). Educational research: contemporary issues and practical approaches (2nd ed.). London: Bloomsbury Academic.

91. West, A. (2014). Academies in England and independent schools in Sweden: policy, privatisation, access and segregation. Research Papers in Education,29(3), 330350. DOI: $10.1080 / 02671522.2014 .885732$

92. West, M. (2010). School-to-school cooperation as a strategy for improving student outcomes in challenging contexts, School Effectiveness and School Improvement: An International Journal of Research, Policy and Practice, 21(1), 93112. http://dx.doi.org/10.1080/09243450903569767

93. Whitty, G. (2008). Twenty years of progress? English education policy 1988 to the present. Educational Management Administration \& Leadership, 36(2), 165-84.

94. Wilkins, A. (2015). Professionalizing school governance: The disciplinary effects of school autonomy and inspection on the changing role of school governors. Journal of Education Policy, 30:2, 182-200. DOI: 10.1080/02680939.2014.941414 
Vol.8, Issue 2, pp.82-103, February 2020

Published by ECRTD- UK

Print ISSN: ISSN 2054-6351

Online ISSN: ISSN 2054-636X

95. Wright, N. (2001). Leadership, "bastard leadership" and managerialism: confronting twin paradoxes in the Blair education project, Educational Management and Administration, 29(3), 275-90.

96. Wrigley, T. (2009). Academies: privatizing England's schools. Soundings.42 (Summer), 47-59.

97. Wrigley, T. (2011). Rapidly improving results: Penetrating the hype of policybased evidence. In: H. M. Gunter (Ed.). The state and education policy: Academies Programme, (pp. 133-145). New York: Continuum International Publishing Group 98. www. Parliament.uk. (2011). Conclusions and recommendations. Retrieved March 8, 2018, https://publications.parliament.uk/pa/cm201011/cmselect/cmpubacc/552/55204.html 